
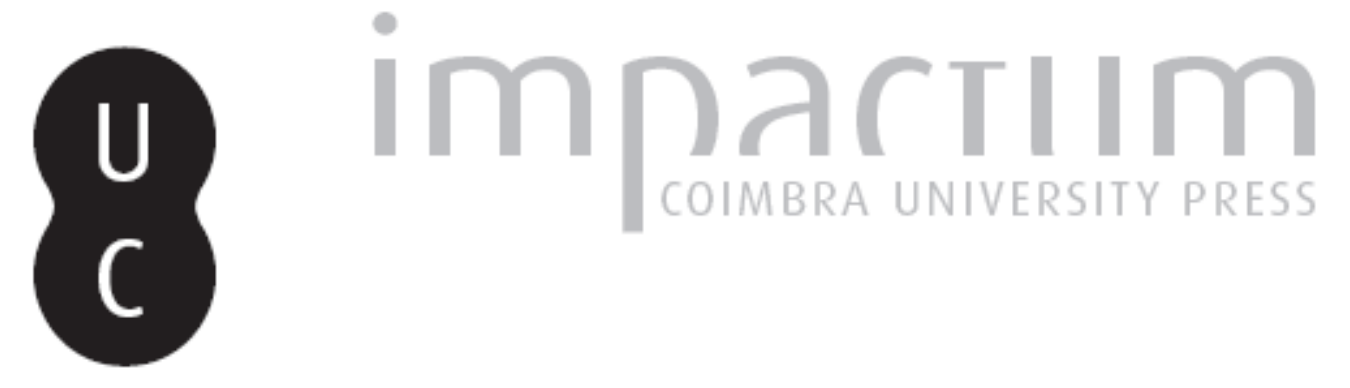

\title{
Plutarch versus Dionysius on the first triumph
}

Autor(es): Weaire, Gavin

Publicado por: International Plutarch Society

URL persistente:

URI:http://hdl.handle.net/10316.2/36385

DOI:

DOI:http://dx.doi.org/10.14195/0258-655X_7_9

Accessed : $\quad$ 26-Apr-2023 06:08:08

A navegação consulta e descarregamento dos títulos inseridos nas Bibliotecas Digitais UC Digitalis, UC Pombalina e UC Impactum, pressupõem a aceitação plena e sem reservas dos Termos e Condições de Uso destas Bibliotecas Digitais, disponíveis em https://digitalis.uc.pt/pt-pt/termos.

Conforme exposto nos referidos Termos e Condições de Uso, o descarregamento de títulos de acesso restrito requer uma licença válida de autorização devendo o utilizador aceder ao(s) documento(s) a partir de um endereço de IP da instituição detentora da supramencionada licença.

Ao utilizador é apenas permitido o descarregamento para uso pessoal, pelo que o emprego do(s) título(s) descarregado(s) para outro fim, designadamente comercial, carece de autorização do respetivo autor ou editor da obra.

Na medida em que todas as obras da UC Digitalis se encontram protegidas pelo Código do Direito de Autor e Direitos Conexos e demais legislação aplicável, toda a cópia, parcial ou total, deste documento, nos casos em que é legalmente admitida, deverá conter ou fazer-se acompanhar por este aviso.

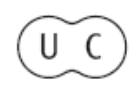




\section{PLOUTARCHOS, n.s.}

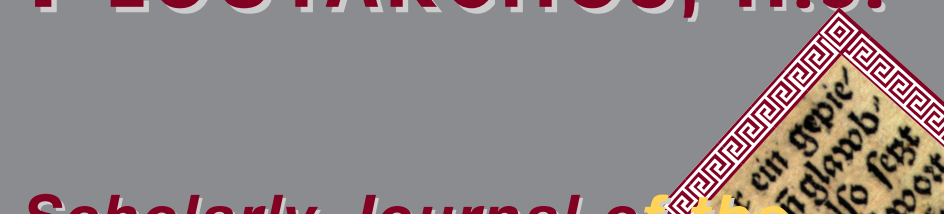

\section{Scholarly Journal o}

International Plut
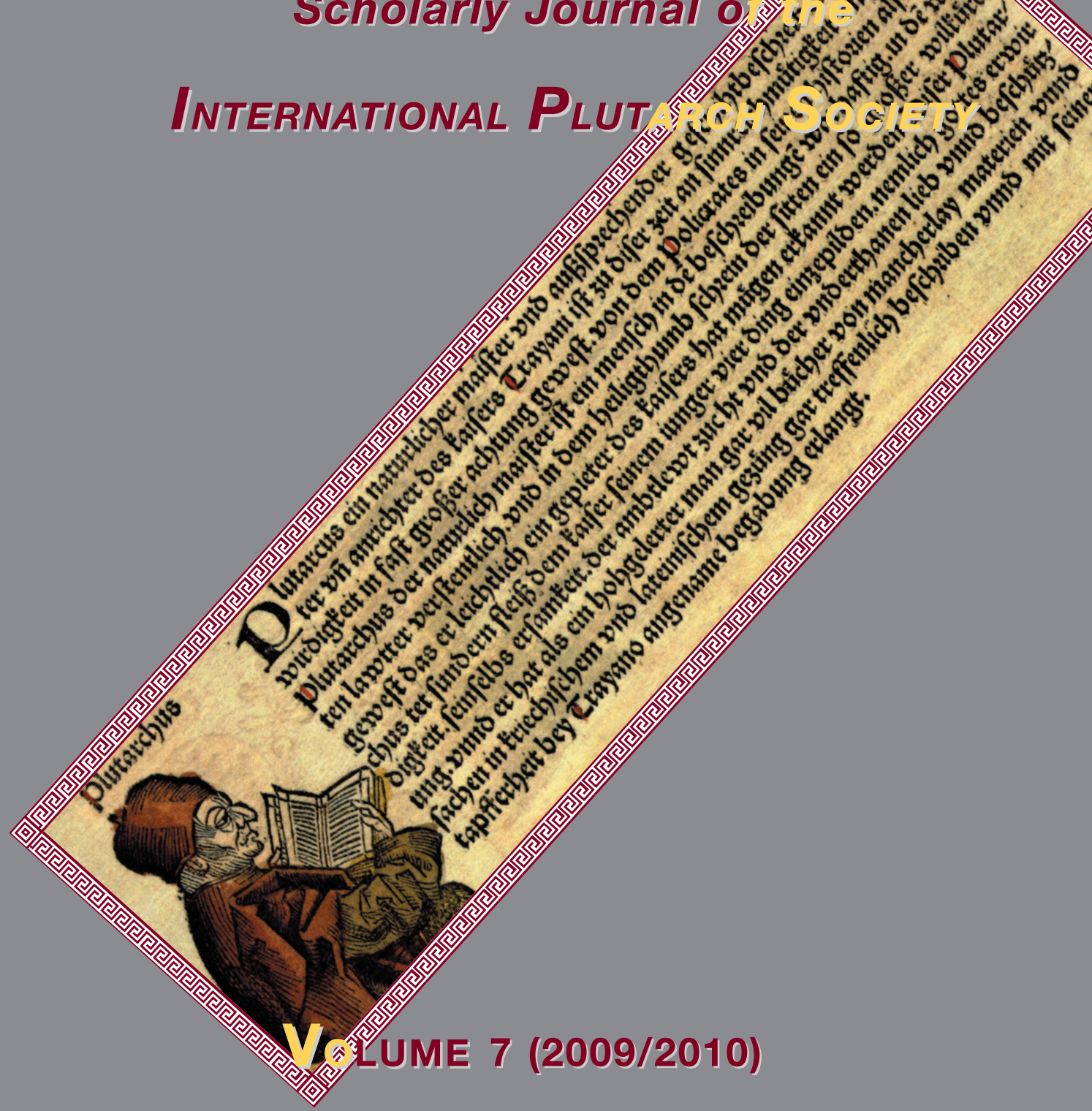

UNIVERSITY OF MÁLAGA (SPAIN) Utah State University, Logan, Utah (U.S.A.) 


\title{
Plutarch versus Dionysius on the first triumph ${ }^{*}$ \\ by \\ Gavin Weaire \\ Hillsdale College, Michigan \\ gweaire@hillsdale.edu
}

\begin{abstract}
Plutarch's account of the establishment of the triumph by Romulus should not be taken at face value, for it contains parody of the version in Dionysius of Halicarnassus. Plutarch's disagreement with Dionysius here further reflects a more fundamental disagreement between the two writers about the legitimate uses of spectacle and fear as political tools.
\end{abstract}

Key-Words: Plutarch, Dionysius of Halicarnassus, Life of Romulus, Triumphs.

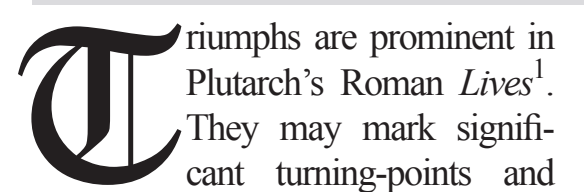

so articulate the structure of a life ${ }^{2}$.

This interest in triumphs is not in itself particularly surprising. The ritual offered attractive material as a preeminent Roman expression of a prominent Plutarchan theme, $\varphi \imath \lambda o \tau \iota \mu \alpha^{3}$. Triumphs also offered contemporary resonance. Triumphal imagery formed

* An earlier version of this argument was presented at the panel ("Plutarch as Antiquarian and Collector of oddities") sponsored by the International Plutarch Society at one Annual Meeting of the American Philological Association in 2008. I am grateful for comments that I received on that occassion.

1 E.g. Publ., 9.5-6; Cam., 7.1-2; 30.1-2; 36.1; Fab, 2.1; 24.3; Marc., 4.3; 8.1-3; 21-22; Flam., 13.6-14.1; Cat. Ma., 11.2; Aem., 30-34; Mar., 12.2-5; 24.1; 27.5-6; Sull., 3.3; 34.1-2; Luc., 37.1-4; Cat. Mi., 29.3-4; 31.2-4; Pomp., 14; 22.1; 45; Caes., 13.1-2; 55.2-4; 56.7-9; Cic., 37.1; note also important "quasi-triumphs" at Sert., 22.2-3; Crass., 32.1-5; Cat. Mi., 39.1. The Moralia display less interest, but triumphs do crop up: e.g. 196E; 282F-283E.

2 E.g. Aem., 34.8-35.3; Pomp., 45-46.4; Caes., 56.7-9; on the significance of the latter see C. Pelling, 1997, p. 222.

3 See F. Frazier, 1988; F. Frazier, 1996, pp. 103-9; T. Duff, 1999, passim esp. pp. 83-87; also B. BuCHER-IsLER, 1972, pp. 12-13, 58-59. 
an important component of the imperial image $^{4}$, not least the image of Trajan, who celebrated three triumphs (one of them posthumously $)^{5}$, and is often represented as a triumphing general ${ }^{6}$.

The following is Plutarch's reconstruction of the first triumph (Rom., 16.5-8):

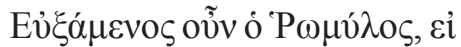

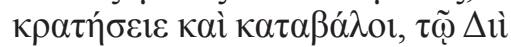

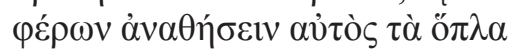

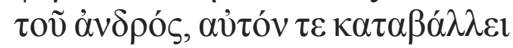

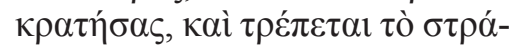

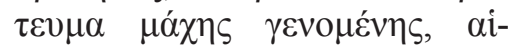

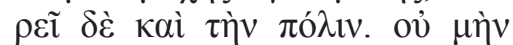

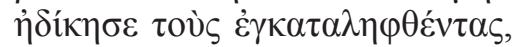
$\dot{\alpha} \lambda \lambda$ ' ì $\tau$ às oíkías $\dot{\varepsilon} \kappa \varepsilon ́ \lambda \varepsilon v \sigma \varepsilon$

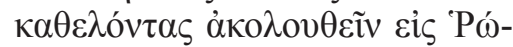

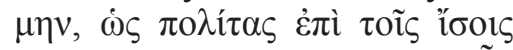

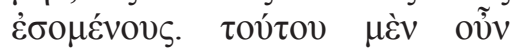

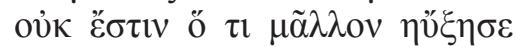

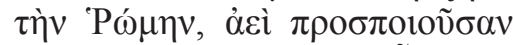

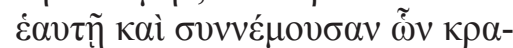

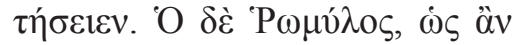

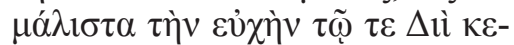

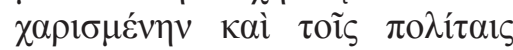

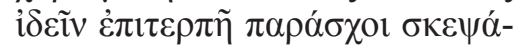

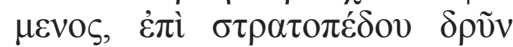

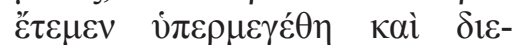

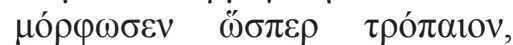

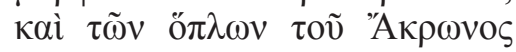

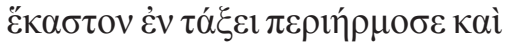

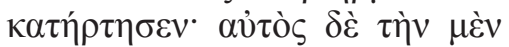
$\dot{\varepsilon} \sigma \theta \tilde{\eta} \tau \alpha \pi \varepsilon \rho \varepsilon \zeta \zeta \dot{\omega} \sigma \alpha \tau o, \delta \alpha \alpha_{\varphi v \eta \eta} \delta^{\prime}$

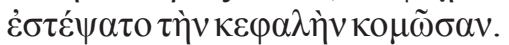

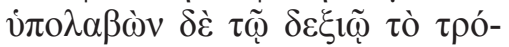
$\pi \alpha 10 v \dddot{\omega} \mu \omega \pi \rho \circ \sigma \varepsilon \rho \varepsilon 1 \delta o ́ \mu \varepsilon v o v$ ò $\rho-$

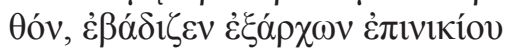

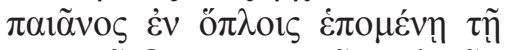

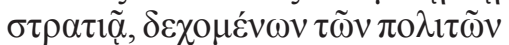

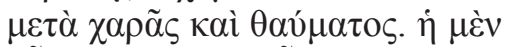

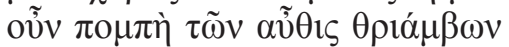

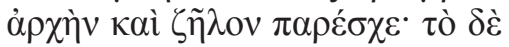

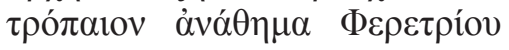
$\Delta$ iòs غ̇ं $\omega v 0 \mu \alpha ́ \sigma \theta \eta$.

So after Romulus vowed that, if he should defeat and strike down his opponent, he would personally carry and dedicate the man's arms to Zeus, he did both defeat and strike down his opponent, and put the opposing army to flight in the battle that took place, as well as capturing the city. But he did not injure his captives at all, except for ordering them to destroy their homes and follow him to Rome, so that they would be full citizens. There is nothing which made Rome stronger than this did, that she always won those she defeated over to herself and made them her partners.

On the topic in general see e.g. E. KüNZL, 1988, p. 106; M. BEARD, 2007, pp. 219-220, 266-272, 275-277, 295-6.

5 Trajan's first triumph (102 A.D.): Dio, 68.10.2; second (107 A.D.): Pliny, Ep., 8.4.2; third and posthumous (117 A.D.): HA, 6.3; see J. Bennett, 2001, pp. 96, 102-3, 204.

6 Most notably on the arch at Beneventum, see see M. Rotili, 1972, pp. 106-112; E. KüNZL, 1988, pp. 25-26; M. Molin, 1994, p. 722; cf. the small relief sculpture of Trajan on a quadriga from Praeneste: E. KüNZL, 1988, p. 28. For triumphal themes on Trajan's coinage see O. Richier, 1997, pp. 598-599; 602; 613; N. MÉTHy, 2000, pp. 373-4. 
But Romulus thought about how could best fulfill his vow in a way that would be gratifying to Zeus and delightful for the citizens to see. He felled an enormous oak-tree in the camp, fashioned it into the form of a trophy, and carefully arranged and fixed each piece of the arms of Acron to it. Then he himself belted his clothes around himself and placed a laurel-wreath upon the flowing hair of his head. He took up the trophy, propped it upright on his right shoulder, and marched, leading a paean in celebration of victory for his army, which followed under arms. The citizens received him with joy and amazement. This procession furnished an origin and model for later triumphs. The trophy was called an offering to Zeus "Feretrius."

Greek authors of the imperial period (including Plutarch) generally make their triumphs conform to a type that displays all of the familiar conventional features ${ }^{7}$. This passage is an exception. Plutarch's first triumph is quite odd. To begin with, Plutarch conflates it with the first dedication of the spolia opima. The rituals are not only both celebrated as an outcome of the same victory; they are, when Romulus celebrates them, exactly the same ritual.

This passage has been used to support modern theories about the origin of the triumph that view the spolia opima as a survival of a simpler early version, or equivalent, of the triumph ${ }^{8}$. In fact, Plutarch's opinion is entirely unparalleled and would probably have been unfamiliar to his ancient readers. No other source identifies the two ceremonies. Few other accounts even have the triumph and the dedication of the spolia opima celebrated as two separate rituals on this occasion. Dionysius of Halicarnassus (2.34) is the only certain example earlier than Plutarch ${ }^{9}$. Strikingly, Livy, who records the dedication of the spolia opima but not the triumph (1.10.5-7), does not connect the two rituals. Plutarch's account may in fact have been his own creation, inspired by artistic images of the tropaiophoric

\section{7}

H. S. Versnel, 1970, pp. 306-313; cf. (apparently) L. Bonfante Warren, 1970, p. 53 n. 31; C. Ampolo \& M. Manfredini, 1988, pp. 313-4; R. M. Schneider, 1990, pp. 187-8; for skepticism see M. Spannagel, 1999, p. 151; H. I. Flower, 2000, pp. 35-46 argues that dedicating the spolia opima was a tradition invented by Marcellus in 221 B.C.

9 The only other certain case is the brief notice in Solinus (1.20); Pliny, Paneg., 17 connects the two ceremonies (without saying anything about shared origins as such). The preserved Fasti triumphales (Inscr. It. XIII.1) record only a triumph for Romulus; see A. DEGRASSI, Inscr. It. XIII.1 (1947) p. 534; 550. However, is possible that a reference to Romulus' dedication of the spolia opima has been lost, provided that such a reference was added after the original inscription: so M. Spannagel, 1999, pp. 250-251.

PLOUTARCHOS, n.s., 7 (2009/2010) 107-124

ISSN 0258-655X 
Romulus ${ }^{10}$.

This is not the only way in which this "triumph" pushes the boundaries of the term. Another unique feature of this triumph narrative is that Romulus processes on foot. The widespread use of the quadriga in both literature and art as shorthand for the triumph makes its absence particularly striking ${ }^{11}$.

Triumph narratives conventionally incorporate lavish description of spoils $^{12}$. Plutarch mentions none (aside from the spolia opima). The punishment of the Caeninenses is limited to ordering them to destroy their homes and come to Rome, implying that they suffer no other loss of property. The role of the defeated enemy in this triumph is also unusual. They comprise part of the procession not as captives, but as new Roman citizens. This is not the only place where a triumph is seen as integrating the defeated into the Roman community, but it is a uniquely extreme case $^{13}$. The Caeninenses, in fact, most resemble the liberated Roman prisoners-of-war, now re-integrated by victory into their native society, that appear in several triumph narratives ${ }^{14}$.

Another oddity is not immediately apparent. It emerges in the light of the subsequent narrative. Plutarch makes no mention of the distinctive regal clothing worn by later triumphing generals. However, he has explicitly described the king wearing it on a different public occasion shortly before this. Romulus uses a crimson toga during the Consualia to signal the Romans to begin the abduction of the Sabine women (Rom., 14.4-5). As a result, the reader is likely to

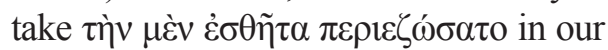
passage to mean that Romulus is dressed similarly here.

But a later passage (Rom., 26.1-2) reveals that Romulus only begins to dress like this habitually at the moment when his rule turns to tyranny. In turn, the toga facilitates Romulus' assassination in one of the versions of his death presented by Plutarch. Its color allows the king's murderers to wrap the bloody dismembered pieces of his corpse in it and so to escape detection. These sinister later passages associate the crimson toga with moral decline and violence.
12 For spoils carried in triumphs see I. ÖstenBerG, 2009, pp. 19-119; cf. E. KüNZL, 1988, pp. 109-111; R. BRILliant, 1999, p. 225.

13 On captives in triumphs see I. ÖstenBERG, 2009, pp. 128-163; on triumphs as a sort of rite of passage that converts a defeated captive into a member of the Roman society, see M. BeARD, 2007, pp. 140-141; I. ÖSTENBERG, 2009, pp. 137-138; 275-276.

14 In Plutarch, note Flam., 13.4-5; Sull., 34.1; Mor., 196E. See I. Östenberg, 2003, p. 265 and $\mathrm{n} .15$ for further instances of the topos. 
This prompts the reader to re-assess the earlier narrative. The appearance of the royal garment in Plutarch's version of the abduction of the Sabine women was an isolated instance. Romulus uses it as a signal to the Romans that it is time to resort to violence; Plutarch uses it to signal to the (re)reader that this is a sinister and ambivalent moment in the narrative ${ }^{15}$. In our passage, on the other

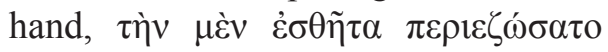
should indicate that Romulus rearranges his ordinary clothes ${ }^{16}$.

Finally, the emotional thrust of this triumph narrative is skewed at best. Triumphs, in Plutarch and elsewhere, mark high points of personal prestige ${ }^{17}$. But the language of honor is absent from this passage. Even the association of the triumph with military victory is remarkably underplayed. Instead, Plutarch emphasizes Romulus' piety towards Zeus and his desire to provide a pleasurable spectacle for the citizenry. The first of these, the fulfillment of the vow, applies especially to the "spolia opima" component of the ritual. The second attaches especially to the processional display (the "triumph" component), a fact Plutarch underlines by describing the pleasurable surprise with which the citizen body receives the procession ${ }^{18}$.

Plutarch only comments explicitly on one of the idiosyncratic features of his version of Romulus triumph: the absence of the emblematic quadriga. This is the occasion for an attack (Rom., 16.8) on the version of events in the Antiquitates Romanae of Dionysius of Halicarnassus:

15 This is not the place to explore Plutarch's fascinatingly ambivalent presentation of the abduction of the Sabine women in detail. Note however the following elements that, when compared to the handling of the incident elsewhere (contrast esp. D. H., 2.30; Livy, 1.9) reflect poorly on Romulus: Plutarch does not have Rome's neighbours refuse intermarriage beforehand and so drive Romulus to this expedient; he raises (even if he labels it unlikely) the possibility that Romulus' motive is the desire of a $\varphi 1 \lambda o \pi$ ó $\lambda \varepsilon \mu \circ \varsigma$ for war and conquest (Rom., 14.1); he emphasizes the Spartan ancestry of the Sabines and their positive qualities, especially their restrained and moderate response to the crime (Rom., 16.1-2). See F. FrAZier, 1996, pp. 269-70 for a more favorable view of the behavior of Plutarch's Romulus on this occasion.

16 Plutarch probably means the cinctus Gabinus (M. Spannagel, 1999, p. 149).

17 Esp. Aem., 34.7; Pomp., 46.1-2; on triumphs as high, if precarious, points of prestige see M. BEARD, 2007, pp. 250-252.

18 N.B. Plutarch next discusses these two elements separately and in this order. First, he surveys the etymology and later history of the spolia opima (Rom., 16.6-8). There follows his attack on Dionysius' account of Romulus' triumph, which incorporates a brief discussion of the later development of this ceremony. This indicates both that Plutarch is conscious that his narrative conflates two ceremonies and that he feels no need to maintain this conflation consistently. 


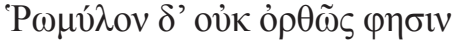

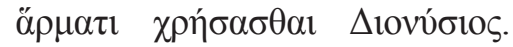

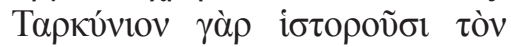

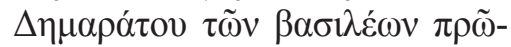

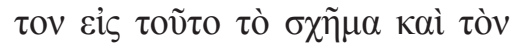

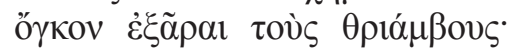

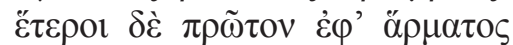

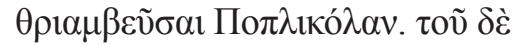

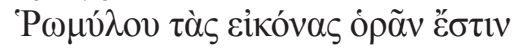

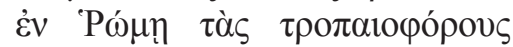
$\pi \varepsilon \zeta \grave{\alpha} \varsigma \dot{\alpha} \pi \alpha ́ \alpha \alpha \varsigma$.

But Dionysius is wrong when he says that Romulus made use of a chariot. For historians record that the first of the kings to raise triumphs to that level of ostentation and pompousness was Tarquinius son of Demaratus. Others record that Publicola was the first to celebrate a triumph in a chariot. It can be seen in Rome that all the tropaiophoric images of Romulus are on foot.

Previous discussions have ascribed limited significance to Plutarch's "correction" of Dionysius. Itgenshorst, in the most recent discussion, sees Dionysius' version of the first triumph as implausibly and anachronistically fullydeveloped ${ }^{19}$. Plutarch then improves this by substituting something more slapdash and historically plausible.
However, Plutarch's confrontation with his predecessor is more pointed than this. Plutarch's words engage closely with Dionysius' commentary on his own description of Romulus' triumph (2.34.3):

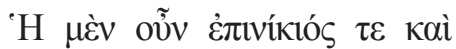

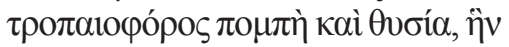

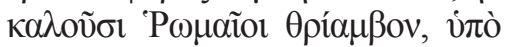
'Р

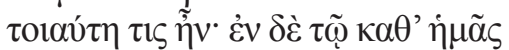

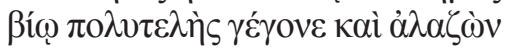

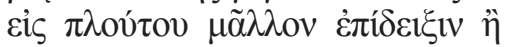

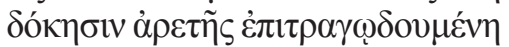

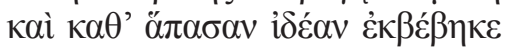

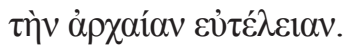

So the procession and sacrifice in celebration of victory and involving the carrying of trophies, which Romans call a "triumph", was like this when it was instituted for the first time by Romulus. But in our time it has become luxurious and boastful, turned into a theatrical display of wealth rather than an exhibition of heroism, and has diverged from the old thrift in every way.

Both authors see the triumph as a benchmark of decent simplicity against which the subsequent moral decline of Rome can be measured ${ }^{20}$. But Plutarch

T. Itgenshorst, 2005, p. 15; cf. C. Ampolo \& M. Manfredini, 1988, pp. 313-4.

20 See M. BEARD, 2007, pp. 289-290. Such ancient accounts have found modern echoes in the notion of the "hellenization" of the triumph in supposed imitation of Hellenistic kings (e.g. A. Bruhl, 1929; L. Bonfante Warren, 1970, pp. 64-65; P. Holliday, 2002, pp. 28 30); this has been convincingly refuted by T. ITGENSHORST, 2006. 
mischievously redefines Dionysius' version of the original triumph (for Dionysius a display of $\dot{\alpha} \rho \varepsilon \tau \eta \dot{~ c h a r a c t e r i z e d ~}$

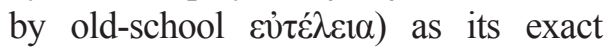
opposite, the degenerate later triumph.

This disagreement is not confined to the quadriga, for Dionysius' triumph conforms to convention in every respect that Plutarch's triumph does not. Dionysius, as we shall see, clearly distinguishes the triumph from the dedication of the spolia opima. His procession apparently contains hostages $^{21}$, and certainly contains more spoils than just the trophy ${ }^{22}$. His Romulus wears regal clothing ${ }^{23}$. His triumph emphatically glorifies the victorious general $^{24}$.

Although this is the first and only explicit mention of Dionysius in Romulus, he is a salient presence elsewhere ${ }^{25}$. Plutarch describes Theseus and

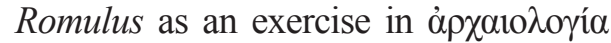
(Thes., 1.3), recalling the topic and title of Dionysius' work. Indeed it is especially Romulus that Plutarch emphasizes in this introduction to the two lives. This focuses particular attention on Roman early history, and so on Dionysius, the author of the only substantial treatment of the topic in Greek.

Thucydides is also a presence ${ }^{26}$. Plutarch may also have been familiar with the De Thucydide, and specifically with its attack on the Archaeology as straightforwardly contrary to the plain indisputable facts of early Greek history (D. H., Th., 19). Plutarch's introduction to Theseus and Romulus, which stresses the fabulous and unreliable nature of the distant past, is well-framed to be a reply to Dionysius' argument ${ }^{27}$. Plutarch also presents a different picture of early Roman history from the one on offer

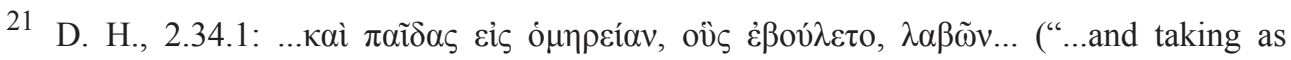
hostages those of the children that he wished...").

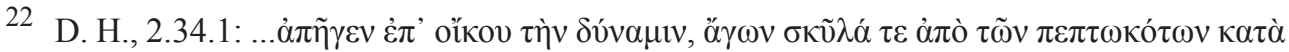

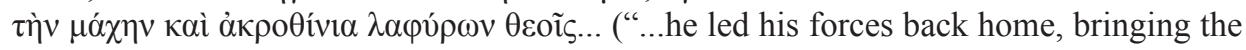
spoils of those who had fallen in battle and the best parts of the loot for the gods...").

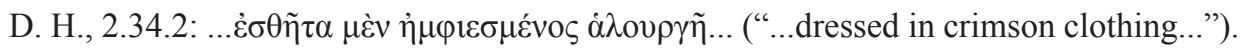

24

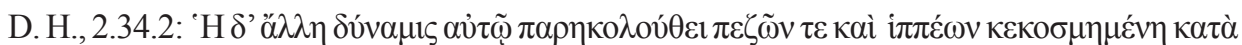

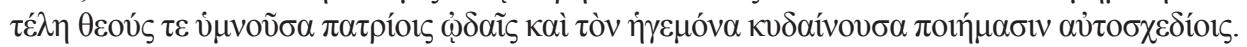
("The rest of the army accompanied him, arranged according to their units. They sang ancestral hymns to the gods and glorified their commander in improvised compositions.").

See E. Gabba, 1991, p.213; C. Ampolo \& M. Manfredini, 1988, p. xlix; A. Scheithauer, 2000, p, 508 and n. 95.

26 See C. Pelling, 2002, pp. 171-195; for Rom. esp. pp. 189 n.1; cf. C. Ampolo \& M. MANFREdini, 1988, pp. xi-xii.

27 See E. GabBa, 1991, p. 214. 
in the Antiquitates Romanae. There, the "real facts" of early Roman history are only obscure because of bias and neglect, and are quite accessible to a diligent historian who is as intimate with Rome as Dionysius is $(1.4-5 ; 7)^{28}$. At the same time, a sceptical reader might feel that Dionysius' famous demonstration of the Greekness of the Romans revealed just how plastic, despite Dionysius' protestations, early Rome could be.

But Plutarch's critique of Dionysius in our passage presents us with a paradox. Plutarch's triumph is a bland and generic ceremony, one easy to analogize to Greek practices. Particularly significant for Plutarch because of its Delphic associations, Romulus wears the laurel. The king leads an apparently spontaneous paean in celebration of victory ${ }^{29}$. He dedicates his enemy's arms to the gods $^{30}$. This demands explanation. How is it that, in ostensible disagreement with Dionysius, Plutarch produces a version of this part of the Roman past that would, if accepted be more compatible with Dionysius' central thesis that the Romans are ancestrally Greek than Dionysius' own version is?
One possible answer is Plutarch's goal here may not be not plausibility, but parody. The Greekness of Plutarch's triumph may mimic and exaggerate Dionysius' dependence on parallels between Greek and Roman customs $^{31}$. Further, the specific Greekness of Romulus would then satirize Dionysius' tendency to idealize the Roman king as a quintessentially Greek founder-figure ${ }^{32}$.

This approach makes the best sense of the end of the digression, where Plutarch argues from the fact that the tropaiophoric images of Romulus at Rome depict the king on foot. This argument depends entirely on Plutarch's conceit that Romulus' triumph and his dedication of the spolia opima are exactly the same event, so that any depiction of one must also depict the other.

But only a very careless reader of the Antiquitates Romanae could fail to observe that Dionysius distinguished between the two ceremonies (2.34.4):

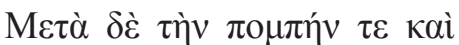

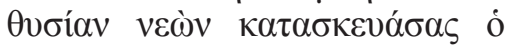

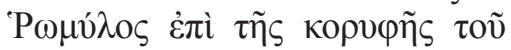

28 See A. Delcourt, 2005, pp. 62-63; C. Ampolo \& M. Manfredini, 1988, p. x.

29 On this practice, see I. RUTHERFORD, 2001, pp. 45-47.

30 Actually carrying a trophy is an impractical feat that in Greek art is largely reserved for the goddess Nike (see K. Woelcke, 1911, 166-168).

31 See E. GabBA, 1991, pp. 105-6; 133-138; 141-143; 153-4; for Plutarch's disagreement with Dionysius' bold thesis see A. Delcourt, 2005, pp. 120-123.

32 On Dionysius' Romulus see E. GabBa, 1991, pp. 154-7; A. Delcourt, 2005, pp. 255-299; for comparison with Plutarch's less idealized version, see A. SCHEITHAUER, 2000, p. 509. 


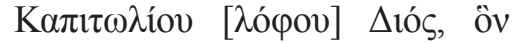

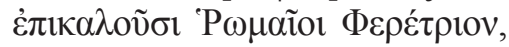

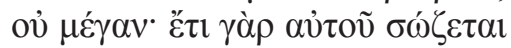

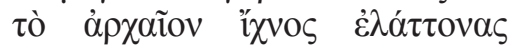

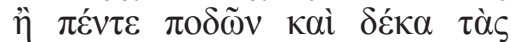

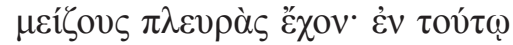

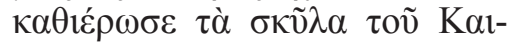

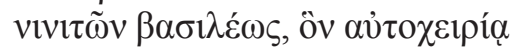

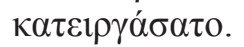

After the procession and sacrifice, Romulus, having built on the crest of the Capitoline a shrine to the Zeus whom the Romans call "Feretrius" (which was not a large shrine, for there survive ancient traces of it, whose longest sides are fifteen feet long), dedicated in this shrine the spoils of the king of the Caeninenses, whom he had overpowered with his own hands.

Romulus is explicitly said to dedicate the spolia opima after the

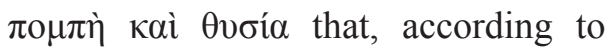
Dionysius, constitute the triumph. On the most plausible interpretation of

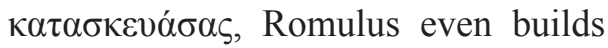
the temple of Jupiter Feretrius in the interim between the two ceremonies. Read seriously, Plutarch offers a hopelessly inadequate argument.

Read as a parodist, however, Plutarch presents himself as a close (but not very charitable) reader of Dionysius. His argument here directs attention to his conflation of two ceremonies. In itself, this parodies Dionysius' characteristic tendency to combine separate traditions to produce composite accounts, often in contrived ways ${ }^{33}$. Further, Plutarch puts his finger on an uncomfortable point in Dionysius' narrative. Dionysius (who is not known for his concise and rapid presentation of events) skims quickly over Romulus' sacrifice before moving on to the topic of the dedication of the spolia opima. This presumably is aimed at directing attention away from a difficulty with the scenario that Dionysius presents. There was as yet (in Dionysius' narrative or elsewhere in the general tradition) no temple of Jupiter Optimus Maximus on the Capitol. So where exactly does Dionysius suppose Romulus to have sacrificed?

There is a further dimension of parody to Plutarch's argument here. Appeal to the images of Romulus at Rome parodies one of Dionysius' own signature argumentative moves: to buttress his authority as Roman expert by lavish display of his autoptic familiarity with Roman remains. Readers might perceive yet another joke at Dionysius' expense. The tropaiophoric Romulus in art is indeed always depicted on foot, but he is also usually

33 Most famously in Dionysius' demonstration of Rome's Greekness by means of a composite account of Rome's origins combining multiple traditions (1.8-90): see A. Delcourt, 2005, pp. 129-155, esp. 142. Note also $A R$, 3.61.1-2 with A. Delcourt, 2005, p. 320. 
depicted in armor. In particular, the king apparently wore armor in his most famous tropaiophoric image, the statue in the Forum of Augustus ${ }^{34}$. The visual evidence supports Plutarch in one respect and undermines him in another. This offers a sharp commentary on Dionysius' selective use of evidence in the service of a strong thesis ${ }^{35}$.

Plutarch's supposed refutation of Dionysius shows how easily Dionysius' favorite weapons can be used against him to witty effect. What is the point of this, and why choose Romulus' triumph as the occasion? Of course, to demolish Dionysius' expertise reinforces Plutarch's own. Such an attack on a key predecessor was a conventional tactic for Greek writers on Rome, going back to Polybius' polemic against Timaeus. Dionysius himself uses the tactic aggressively in the first book of the Antiquitates Romanae ${ }^{36}$. Plutarch's use of the same move against Dionysius is a nice irony.

Plutarch is certainly invested in his authority as an expert on Rome. But there is more to this than just a witty variant on a standard game. Plutarch singles out the quadriga for attention. This focuses attention on a sensitive piece of interpretative work by Dionysius (2.34.2):

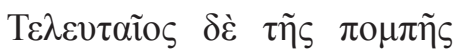

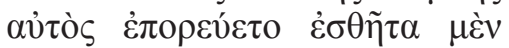

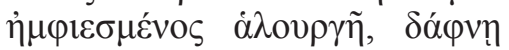

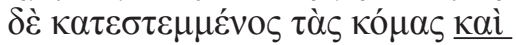

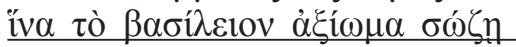
$\tau \varepsilon \theta \rho i ́ \pi \pi \omega \pi \alpha \rho \varepsilon \mu \beta \varepsilon \beta \eta \kappa \omega ́ s$.

He himself came at the end of the procession, dressed in crimson clothing and with his hair wreathed with laurel, and also, so that he might preserve his kingly status, going by in a quadriga.

There is nothing implausible about the idea that the quadriga might have functioned in the triumph as the visual articulation of status differences. Plutarch's predecessor may have displayed his intimate familiarity with Roman society a little too well. In particular, Plutarch may have found Dionysius' use of $\sigma \omega ́ \zeta n$ unsettling. There is no apparent threat to Romulus' position at this point in the narrative. Dionysius depicts a world in which legitimate authority is constantly under threat and must be buttressed through spectacular power.

34 For a reconstruction of the statue of Romulus in the Forum of Augustus and a survey of the preserved depictions of the tropaiophoric Romulus, see M. Spannagel, 1999, pp. 132136. On Plutarch's autopsy of monuments at Rome see J. BuCKLER, 1992, pp. 4821-4825.

35 N.B. Rom. 24.3, where Romulus adds a very triumphal image of himself, crowned by a Victory, to a quadriga that he has taken as spoils (cf. D. H., 2.54.2, where the incident is recounted in connection with Romulus' second triumph). Triumphing in a quadriga is apparently not as alien to Romulus, or his artistic representation, as Plutarch pretends at first.

36 Criticism of Timaeus and Polybius: $1.6 .1 ; 1.7 ; 1.32 .1-2 ; 1.67 .4 ; 1.74 .1,3-4$. 
Such spectacular power involves, for Dionysius, the capacity to inspire fear (2.29.1):

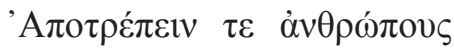

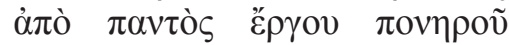

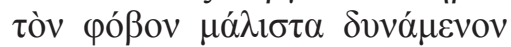

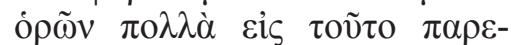

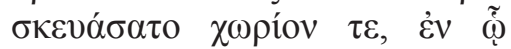

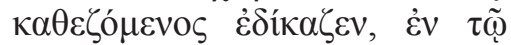

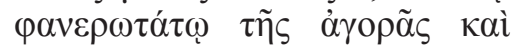

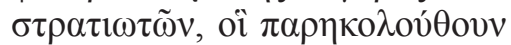

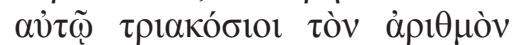

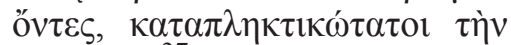

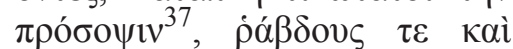
$\pi \varepsilon \lambda \varepsilon \dot{\kappa} \kappa \varepsilon 1 \zeta \quad$ v $\pi$ ' $\alpha v \delta \rho \tilde{\omega} \nu \quad \delta \omega ́ \delta \varepsilon \kappa \alpha$

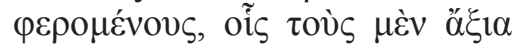

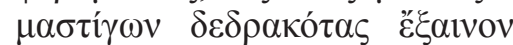
$\dot{\varepsilon} v \quad \dot{\alpha} \gamma 0 \rho \tilde{\alpha}, \tau \tilde{\iota} \nu \delta \grave{\varepsilon} \tau \dot{\alpha} \mu \dot{\varepsilon} \gamma 1 \sigma \tau \alpha$

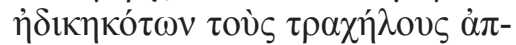

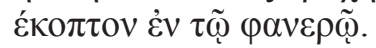

Seeing that fear was the thing most able to turn people away from all evil deeds, he instituted many things with this aim: the location in which he sat to give judgment, in the most visible part of the Forum and his escort of soldiers, who were three hundred in number, an utterly terrifying sight to see, and the rods and axes born by twelve men, with which they flogged in the Forum those who had committed crimes deserving of the lash, and beheaded in public view those who were guilty of the greatest crimes.

This is the final item in the socalled "Constitution of Romulus" (2.729) and is therefore a key passage in Dionysius' presentation of Romulus' governance as a whole ${ }^{38}$. The idealized good king Romulus (as he still is at this point in Dionysius' narrative) displays himself with his retinue in a prominent place in order to terrify his subjects and so sustain public morality.

Plutarch also was capable of viewing the triumph as an exercise in inspiring fear. He identifies the terrifying spectacle presented by the "belligerent" triumph as one of the main elements that distinguishes it from the "peaceful" ovation (Marc., $22)^{39}$. Therefore, what is at issue between Plutarch and Dionysius is probably not the interpretation of the

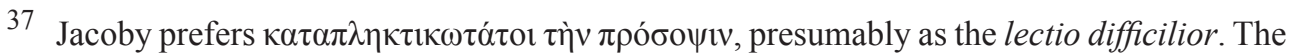

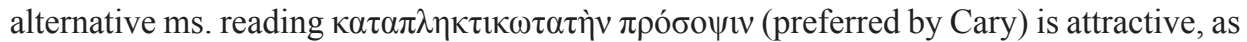
it makes the sentence substantially clearer. In any case, the overall thrust of the passage is not affected.

38 On the "Constitution of Romulus" see, most recently, A. Delcourt, 2005, pp. 272-278. The much-debated question of whether it derives from some single previous source or not is not material here, since Plutarch and his contemporaries probably did not read this passage with this problem in mind.

39 Cf. Cam., 7.1-2, where yoking white horses to the quadriga means that Camillus triumphs $\sigma о \beta \alpha \rho \tilde{\omega} \varsigma$, "in an intimidatingly pompous way." 
"normal" triumph with a quadriga as an exercise in fear, but rather the legitimacy of using public spectacle (or at any rate this particular form of public spectacle) for this purpose $\mathrm{e}^{40}$. A striking parallel is presented by the passage (already mentioned) when Plutarch describes how Romulus adopts the behavior which will cause his downfall (Rom., 26.1-2):

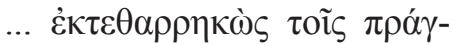

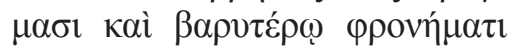

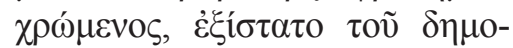

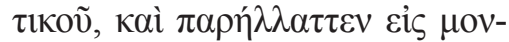

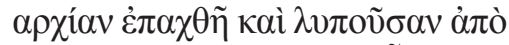

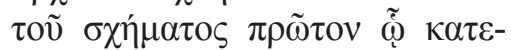

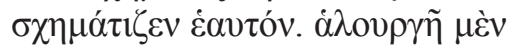

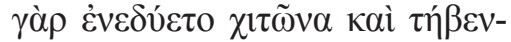

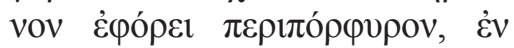

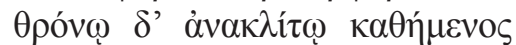
$\dot{\varepsilon} \chi \rho \eta \mu \alpha ́ \tau ı \zeta \zeta v$.

...he grew utterly confident because of his achievements and adopted a more overbearing and arrogant spirit, so that he lost the common touch and transformed his rule into monarchy, which was hateful and distressing, firstly, due to the ostentation with which he began to present himself. He started to clothe himself in a crimson tunic and to wear a toga with a crimson border, and also he conducted public business sitting on a reclining throne.
This is also a response to Dionysius. Much like Plutarch's version of Romulus' triumph, it redefines Romulus' projection of a terrifying image as illegimate and tyrannical ${ }^{41}$. The point is restated in the synkrisis (Comp. Thes.-Rom., 2):

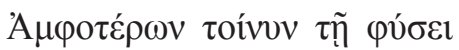

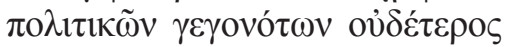

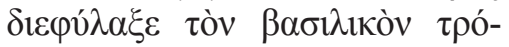
$\pi \circ v^{*} \dot{\varepsilon} \xi \dot{\varepsilon} \sigma \tau \eta \delta \dot{\varepsilon} \kappa \alpha i ̀ ~ \mu \varepsilon \tau \dot{\varepsilon} \beta \alpha \lambda \varepsilon \mu \varepsilon-$

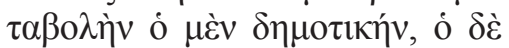

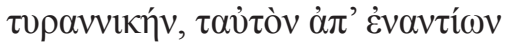

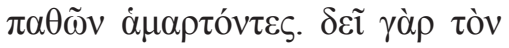

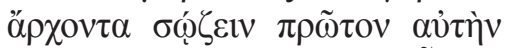

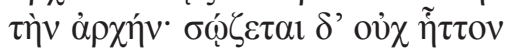

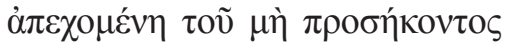

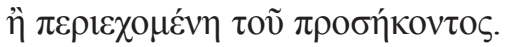

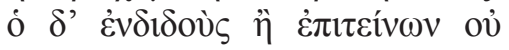

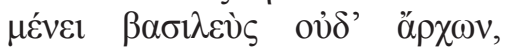

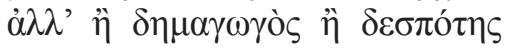

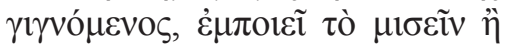

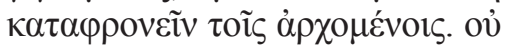

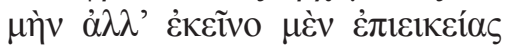

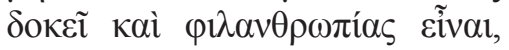

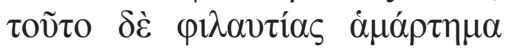

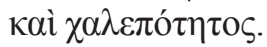

Despite the fact that they were both naturally statesmanlike, neither man kept his kingly character. Each abandoned it and changed, one into a democrat, the other into a tyrant, making the same mistake under the influence of diametrically opposed passions. For the

40 Plutarch does not completely exclude fear as a rhetorical instrument for the statesman (e.g. Per., 15.4; see S. SAÏD, 2005, pp. 18-24, esp. 24).

41 Cf. Num., 7.4 where Numa dispenses with Romulus' bodyguard (praised by Dionysius) as inimical to proper relations between king and subject. 
ruler should first preserve his rule itself.... and the man who yields or overstretches it does not remain a king or ruler. Instead, having become either a rabble-rouser or an autocrat, he induces the ruled to hate him or to despise him. Nevertheless, the former mistake appears to derive from mildness and humanity, while the latter mistake appears to be the product of selfishness and harshness.

In Plutarch's triumph narrative, Romulus notably exhibits these anti-

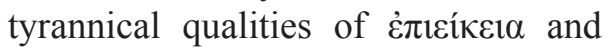
$\varphi \imath \lambda \alpha v \theta \rho \omega \pi i \alpha$ in his mild handling of the Caeninenses ${ }^{42}$.

Östenberg has studied how the triumph in performance constructed the Roman community as a unified whole in opposition to the defeated enemy ${ }^{43}$. This Roman community that the triumph constructed was larger than the citizen community. Among others, the triumph incorporated allied kings and other notables as spectators in the crowd whose gaze added to the humiliation of the defeated. In so doing, the triumph created a cleavage between these Roman allies and the defeated, even though the latter were often their fellow-nationals and sometimes their close relatives ${ }^{44}$. One might further observe that fear (of the consequences of defection) was also part of the triumph's message for such "quasi-Romans."

This relates the triumph closely to Dionysius' central theme. What Östenberg sees the triumph doing is close (but not identical) to what Dionysius does in the Antiquitates Romanae. He erases the distinction between Roman and nonRoman, specifically between Roman and Greek, not least in his own $\tilde{\eta} \theta$ o which offers an exemplary instance of harmonious identification with Rome.

This entails reshaping the triumph itself. Dionysius converts the triumph into a vehicle for the impress of monarchic authority rather than a celebration of foreign victory. This no doubt reflects famous Augustan developments in the role of the triumph ${ }^{45}$. In fact, it may be a specific response to the (probably ongoing) construction of the Forum of Augustus, which linked the image of Augustus triumphing on his quadriga with that of

42 On this and related qualities as political ideals for Plutarch see H. MARTIN JR., 1961; J. DE Romilly, 1979, pp. 275-305; G. J. D. Aalders, 1982, pp. 46-47; L. DE Blois, 1992, p. 4601; F. FrAZIER, 1996, pp. 231-271. For possible connections with specifically Trajanic ideology, see PM. T. SchetTino, 2002.

43 I. Östenberg, 2009, passim esp. pp. 262-292; cf. R. Brilliant, 1999, p. 222; M. Beard, 2007, pp. 119-128.

44 I. ÖstenBerg, 2009, p.156.

45 For an exploration of this passage's relationship to Augustan ideology see T. ITGENSHORST, 2006, pp. 55-56; cf. R. M. SCHNEIDER, 1990, pp. 200-201. 
Romulus dedicating the spolia opima ${ }^{46}$.

But Dionysius adapts Augustan themes to further his own agenda of erasing the distinction between Romans and Greeks, without excluding any particular group of Greeks - such as opponents of Rome. A triumph as Dionysius presents it has an equivalent message for all, whether citizens, allies, or the defeated in the procession. All can be united in fearful reverence for the monarch.

Plutarch's parodic triumph offers a version of incorporation into the Roman community that counters Dionysius'. Defeated non-Romans are incorporated both physically and legally. The conquered Caeninenses accompany Romulus back to Rome to become full citizens. This is a much more extreme picture than the one presented by Dionysius (2.34.3-7). Nothing in Plutarch's subsequent account distinguishes these new citizens and their response to the triumph from the old.

But where Dionysius incorporates by generalizing fear, Plutarch removes fear completely. He instead generalizes another element of the crowd's response.
The aim and effect of Romulus' spectacle is not fear, but pleasure ${ }^{47}$. In place of an elevated monarch as guarantor of public morality through fear, we have a nonthreatening entertainer-in-chief. This suggests that the proper function of a triumph is rather trivial. Here, as frequently elsewhere in Plutarch, spectacle is largely a means for the statesman to gratify the masses without doing any harm, and perhaps with a certain civilizing effect. The reader of Romulus might especially think of Numa's use of the "agreeable

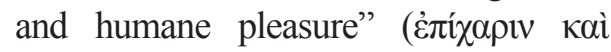
$\varphi \iota \lambda \alpha^{\prime} v \theta \rho \omega \pi \mathrm{ov} \dot{\delta} \delta$ ovív) of processions and other public ceremonies to win popularity and soften the warlike Roman national character (Num., 8.2-3) ${ }^{48}$.

Plutarch's critique of Dionysius arises from serious disagreements of political thought. Why, then, is it cast as a parody? Familiar strategies of "safe criticism" may supply part of the answer ${ }^{49}$. Plutarch's critique of Dionysius has inevitable implications for the triumphal imagery that surrounded the emperor and comprised part of the terrifying image that (at least in the minds

Book I of the Antiquitates Romanae was completed in 8 or 7 B.C. (1.7.2), and book II presumably cannot have been disseminated to readers much later. The Forum of Augustus was apparentlyopened at somepointbetween 6and2B.C.(see M. SPANNAGEL, 1999, pp. 16-20; also J. GeIGER, 2008, pp. 53-61, esp. 59-61). However, some elements must have been visible before the whole was completed, and the projected scheme may have been public knowledge.

On triumphs as joyous occasions see I. ÖstenBERG, 2009, p. 265; cf. R. BrILLIANT, 1999, p. 222.

48 Cf. also esp. Per., 11.4; Mor., 802D-E.: see L. DE Blois, 1992, 4600; S. SAÏD, 2005, pp. 24-25. On Plutarch's Numa as the ideal king/emperor, see G. J. D. AALDERs, 1982, pp. 42-43; P. A. STADTER, 2002, pp. 236-8.

49 The term goes back to F. AHL, 1984. 
of Romans) intimidated potential rebels and foreign enemies into submission ${ }^{50}$. Insofar as it derived from a general view of spectacle as possessing only a very limited importance in politics, his critique had implications for the ways in which power was constructed in the Roman world.

But there may be another reason. Romulus obviously might stand in for the Romans in general, or the emperor in particular ${ }^{51}$. But he might also stand in for any other official, since public spectacle was part of holding even the most minor local offices. The image of a crowdpleasing Romulus, processing on foot and wearing the laurel of a Delphic priest is curiously similar to the one Plutarch presents of himself (Mor, 792F):

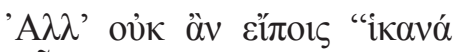

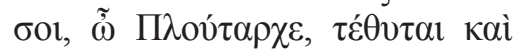

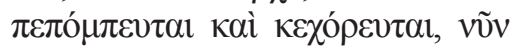

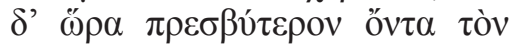

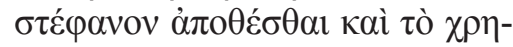

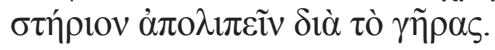

But you would not say "Plutarch, that's enough sacrificing, processing, and chorus-dancing from you! Now that you're older, it's time to take off the wreath and abandon the oracle because of your age."
The talents of Plutarch the religious official are also displayed by Plutarch the author. By employing parody, Plutarch makes his literary triumph an entertainment in itself.

\section{BIBLIOGRAPHY}

AalDERs, G. J. D.,

- Plutarch's Political Thought, Verhandl. Nederl. Akad. van wetensch. Afd. Letterkunde, 116, Amsterdam, Oxford, and New York, 1982.

AнL, F.,

- "The Art of Safe Criticism in Greece and Rome", AJP 105 (1984) 174-208.

Ampolo, C. \& Manfredini, M.,

- Plutarco: Le vite di Teseo e di Romolo, Verona, 1988.

Beard, M.,

- The Roman Triumph, Cambridge, Mass. and London, 2007.

BennetT, J.,

- Trajan: Optimus Princeps, Bloomington and Indianapolis, 2001² (1997).

BLoIs, L. DE,

- "The perception of politics in Plutarch's Roman 'Lives", $A N R W$ II.33.6 (1992) 4568-4623.

Bonfante WARREn, L.,

- "Roman Triumphs and Etruscan Kings: The Changing Face of the Triumph", JRS 60 (1970) 49-66.

BrilLiant, R.,

- “'Let the Trumpets Roar!' The Roman Triumph" in Bergmann, B. and Kon-

Cf. Pliny, Paneg., 16.3-17: Trajan will earn a triumph and would dedicate the spolia opima, except that all foreign kings will be too terrified to face him in combat. See further S.P. MATTERn, 1999, pp. 162-210 passim.

51 However, the image of Romulus is not particularly prominent in Trajan's coinage, as compared to his successors, and the tropaiophoric Romulus first appears on Hadrian's coins: see J.-P. Martin, 1999, pp. 330-336; cf. R. M. Schneider, 1990, 189-190. 
Doleon, C. (ed.), The Art of Ancient Spectacle, New Haven and London, 1999, pp. 221-229.

BRIQUEL, D.,

- "Trois études sur Romulus" in BLOCH, R. (ed.), Recherches sur les religions de l'antiquité classique, Geneva and Paris, 1980, pp. 267-346.

BRUHL, A.,

- "Les influences hellénistiques dans le triomphe romain", MEFRA 46 (1929) 77-95.

BUCHER-IsLER, B.,

- Norm und Individualität in den Biographien Plutarchs, Berne and Stuttgart, 1972.

BuCKLER, J.,

- "Plutarch and Autopsy", ANRW II.33.6 (1992) 4821-4825.

Delcourt, A.,

- Lecture des Antiquités romaines de Denys d'Halicarnasse: Un historien entre deux mondes, Brussels, 2005.

DufF, T.,

- Plutarch's Lives: Exploring Virtue and Vice, Oxford, 1999.

Flower, H. I.,

- "The Tradition of the Spolia Opima: M. Claudius Marcellus and Augustus" CA 19 (2000) 34-64.

Frazier, F.,

- “A propos de la 'philotimia' dans les 'Vies': quelques jalons dans l'histoire d'une notion" RPh 62 (1988) 109-27.

- Histoire et morale dans les Vies parallèles de Plutarque, Paris, 1996.

GABBA, E.,

- Dionysius and the History of Archaic Rome, Berkeley and Los Angeles, 1991.

GeIger, J.,

- The First Hall of Fame: A Study of the Statues in the Forum Augustum, Mnemosyne Suppl. 295, Leiden and Boston, 2008.

Holliday, P. J.,

- The Origins of Roman Historical Commemoration in the Visual Arts, Cambridge, 2002.
ITGENSHORST, T.,

- Tota illa pompa: Der Triumph in der römischen Republik, Göttingen, 2005.

- "Roman Commanders and Hellenistic Kings: On the 'Hellenization' of the Republican Triumph", AncSoc 36 (2006) 51-68.

KüNZL, E.,

- Der römische Triumph: Siegesfeiern im antiken Rom, Munich, 1988.

MARTIN JR., H.,

- "The Concept of Philanthropia in Plutarch's Lives", AJP 82 (1961) 164-75.

MARTin, J.-P.,

- "Les themes de l'épopée romaine dans la numismatique imperiale" in Blanc, N. and Buisson, A. Imago antiquitatis; religions et iconographie du monde romaine: Mélanges offerts à Robert Turcan, Paris, 1999, pp. 329-340.

MatTern, S. P.,

- Rome and the Enemy: Imperial Strategy in the Principate, Berkeley and Los Angeles, 1999.

MÉTHY, N.,

- "Éloge rhétorique et propagande politique sous le Haut-Empire: L' exemple du Panégyrique de Trajan", MEFRA 112 (2000) 365-411.

Molin, M.,

- "L'Arc de Trajan à Benevent: un monument de la première partie du regne" in BoHec, Y. Le (ed.),

- L'Afrique, la Gaule, la Religion et l'epoque romaine: Mélanges à la memoire de Marcel le Glay, Brussels, 1994, pp. 716-722.

ÖstENBERG, I.,

- Staging the world: Rome and the other in the triumphal procession, Diss. Lund, 2003.

- Staging the world: Spoils, Captives, and Representations in the Roman Triumphal Procession, Oxford, 2009.

Pelling, C. B. R.,

- "Plutarch on Caesar's fall", in MosSMAn, J., (ed.), Plutarch and his In- 
tellectual World: Essays on Plutarch, London, 1997, pp. 215-232.

- Plutarch and History: Eighteen Studies, London, 2002.

PicARD, G. C.,

- Les trophées romaines: Contribution à l'histoire de la Religion et de l'Art triomphal de Rome, Paris, 1957.

RICHIER, O.,

- "Les thèmes militaires dans le monnayage de Trajan”, Latomus 56 (1997), 594-613.

Romilly, J. De,

- La douceur dans la pensée grecque, Paris, 1979.

Rotili, M.,

- L'Arco di Traiano a Benevento, Rome, 1972.

RUTHERFORD, I.

- Pindar's Paeans: A Reading of the Fragments with a Survey of the Genre, Oxford, 2001.

SAÏD, S.,

- "Plutarch and the People in the Parallel Lives" in Blois, L. DE, Bons, J., Kessels, T. \& Schenkeveld, D. M. (ed.), The Statesman in Plutarch's Works: proceedings of the sixth international conference of the International Plutarch Society: Nijmegen/Castle Hernen, May 1-5, 2002: volume II: the statesman in Plutarch's Greek and Roman Lives, Leiden \& Boston, 2005, pp. 7-25.

Scheithauer, A.,

- "Romanum imperium a Romulo exordium habet: Das Bild des Romulus bei
Cicero, Dionys von Halikarnass, Livius und Plutarch" in Haltenhoff, A. \& Mutschler, F.-H., Hortus litterarum antiquarum: Festschrift für Hans Armin Gärtner zum 70. Geburtstag, Heidelberg, 2000, pp. 495-513.

SchetTino, M. T.,

- "Trajan's Rescript De bonis relegatorum and Plutarch's Ideal Ruler", in Stadter, P. A. and Stockt, L. VAN DER, Sage and Emperor: Plutarch, Greek Intellectuals and Roman Power in the Time of Trajan (98-117 A.D.), Leuven, 2002, pp. 201-212.

SCHNEIDER, R. M.,

- "Augustus und der frühe römische Triumph”, JDAI 105 (1990), 167-205.

Spannagel, M.

- Exemplaria principis: Untersuchungen zu Entstehung und Ausstattung des Augustusforums, Heidelberg, 1999.

Stadter, P. A.,

- "Plutarch and Trajanic Ideology", in Stadter, P. A. and StockT, L. VAN DER, Sage and Emperor: Plutarch, Greek Intellectuals and Roman Power in the Time of Trajan (98-117 A.D.), Leuven, 2002, pp. 227-241.

VERSNEL, H. S.,

- Triumphus: an inquiry into the origin, development and meaning of the Roman triumph, Leiden, 1970.

WoElcke, K.,

- "Beiträge zur Geschichte des Tropaions", BJb 120 (1911) 127-199. 